\title{
Marketing Intelligence and Big Data: Digital Marketing Techniques on their Way to Becoming Social Engineering Techniques in Marketing
}

\author{
Prof. Dr. habil. Jan Lies \\ FOM University of Applied Science, Dortmund (Germany)
}

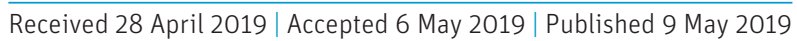

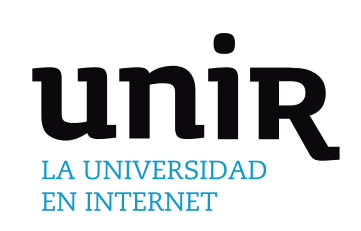

\section{ABSTRACT}

\section{KEYWORDS}

This contribution reviews the vast scope of digital application areas, which shape the digital marketing landscape and coin the present term "marketing intelligence" from a marketing technique point of view. Additionally, marketing intelligence as social engineering techniques are described. The review ranges from digital IT- and big data marketing until marketing 5.0 as digitalized trust marketing. The multiplicity of applications and interdependencies of the digital and social techniques reviewed should show that big data and marketing intelligence have already become a marketing reality. It becomes clear that marketing is witnessing a methodological, technical and cultural paradigm shift that augments and amplifies traditional outbound marketing with inbound marketing.

\author{
Marketing Intelligence, \\ Digital Marketing, Big \\ Data Marketing, Social \\ Engineering, Marketing \\ 5.0. \\ DOI: 10.9781 /ijimai.2019.05.002
}

\section{INTRODUCTION}

$\mathrm{M}$ ARKETING intelligence is certainly not a new term by any means. Nevertheless, it is currently quite common in both theory and practice. The following descriptions of techniques and social engineering methods of marketing intelligence have three goals:

1. The explanations are, without claiming to be overly exhaustive, intended to point out the vast scope of digital application areas, which shape the digital marketing landscape and coin the present term "marketing intelligence" from a marketing technique point of view.

2. Additionally, marketing intelligence as social engineering techniques are described. The multiplicity of applications and interdependencies of the digital techniques reviewed should show that big data and marketing intelligence have already become a marketing reality. What happens in marketing practice concerning marketing Intelligence? It will be shown that digital marketing undergoes a shift from digital technologies to social engineering practices and vice versa. Thus, snapshots of the digital marketing evolution will be taken. They will show that marketing intelligence has already developed beyond its "embryonic status." [1]

3. Particularly marketing techniques like "search engine marketing" and "content marketing" are currently shaping IT Marketing as well as online and social media marketing. They also have an effect beyond the online world. Their impact on marketing practice reveals a new paradigm of marketing, known as Marketing. 4.0, which means an integration of value-based marketing and digitalization.

By utilizing and reflecting on literature regarding marketing techniques

* Corresponding author.

E-mail address: jan.lies@jan-lies.de and methods such as the applied research method of this contribution, it becomes clear that we are witnessing a paradigm shift that augments and amplifies traditional outbound marketing with inbound marketing.

\section{Marketing Intelligence as Digital Marketing} TECHNIQUES

\section{A. Introduction of Marketing Intelligence from a Digital Point of View}

This section introduces marketing from a digital-technological point view, following the popular digitalization processes of corporations. This review thus also describes the current landscape of digital marketing.

Digitalization is supposed to be "unavoidable" [2], i.e. it becomes the foundation of applied marketing. With regards to digital marketing in combination with web-based services, marketers are experiencing an epoch "(...) of technology explosion and easy access to it by consumers (...)." [3]

\section{1) Marketing Intelligence as IT-marketing and Big Data Marketing}

The introductory part of this paper concentrates on the term "marketing intelligence" in order to trace the path from digital data techniques to social engineering.

The term "intelligence" is anything but new. As early as the 1960s, Kelley formulated the significance of marketing intelligence for management in the age of the information revolution. Even then, an increase in data volumes had been diagnosed [4]: Market information can be compared with that of military intelligence services. Top management staff must set up information channels at all data collection points. He proposes to create a novel position of "vice president of intelligence service" and emphasizes the importance of the 
data for economic research, marketing research, market information, and management information. This information must then be verified and validated, i.e., checked and evaluated, for its significance and relevance for a respective company's divisions.

Today - almost 60 years later - marketing 4.0 is the term used to discuss digitalization in marketing, particularly in IT marketing. This term will be the topic of the second section of this contribution (see III.9), where marketing intelligence as social engineering will be discussed, as marketing 4.0 doesn't refer to a specific digital marketing technique, but expresses a social application of it.

Basically "the term marketing intelligence refers to developing insights obtained from data for use in marketing decision-making. Data mining techniques can help to accomplish such a goal by extracting or detecting patterns or forecasting customer behavior from large databases." [5] Traditionally data research relied on market surveys to do consumer research. With the analysis tools of big data, key factors for marketing decisions can be automatically monitored, e.g. by mining social media data. [5]

The implementation-oriented beginning of IT marketing could already be witnessed in the 1990s. IT Marketing refers to the analysis, planning, and implementation of marketing with the help of information technology (IT) and with that the current increase of webbased applications. In the 1990s, many companies began to transfer customer information to electronic databases. At the end of the 1990s, the CRM (customer relationship management) debate arose, often with the goal of integrating sprawling data collection and, from today's perspective, marking a starting point for digitalization in marketing. However, this had already begun before with desktop publishing and digitalized media production at the end of the 1980s and continued with the introduction of call center technologies. [6] Email marketing from around the 1990s continued this development even further. [7]

At about the same time, business and marketing intelligence was being discussed. Jenster/Solberg Soilen describe the traditional paths of intelligence research. This originally began with military information in the 1960s in the US and today shapes a primarily technical-analytical data perspective. [8]

The status quo of marketing intelligence research is still considered to be in its infancy and occasionally even described as "embryonic". [9] The implementation of marketing intelligence systems in practice will depend on whether and how quickly it is possible to find a way out of the complexity of economic statistics, IT and technocracy and to transfer it into simple applications, so that pragmatics [10], i.e., pragmatic analysis methods, find their way into the breadth of marketing practice. Here, applications are making rapid progress in the form of cloud, i.e., web-based, marketing software.

The following overview of marketing techniques and methodical marketing influences will show that marketing intelligence has long been an implicit office standard, irrespective of specific big data solutions, systems or projects. Marketing intelligence is already an implicit standard, because the term intelligence is often not even mentioned in science and practice, but nevertheless impacts marketing practice as social engineering.

\section{2) Marketing Intelligence as Search Engine Marketing}

Search engine marketing and the content marketing based thereon will show in the following that the marketing paradigm, at least in online marketing, is currently determined by an outside-in approach. The term "digital marketing" has developed with the spread of digital communication instruments, channels, and processes [11] and uses digital customer data to secure and implement marketing decisions.

“(...) Search Engine Optimization or SEO is essentially tweaking your website so that it comes up naturally or organically in search results on Google, Yahoo, Bing or any other search engine.” [3] In recent years, what search engines discern as good content has become more and more similar to what a human internet user discerns as good content. In the past - until around 2010 - it was sufficient to place keyword-optimized texts with a keyword density of five percent on a simple website and then buy masses of backlinks on the web. Since the end of 2010, Google has been using various algorithm updates to conduct content quality offensives, and has implemented sanctions including harsh penalties for misdemeanors by listing websites with lower or no hits at all.

The basic technologies for recognizing good search results are artificial intelligence (software that can perceive, justify, act and adapt), machine learning (generic term for all processes that enable machines to generate knowledge from experience) and deep learning (working with artificial neural networks to achieve particularly efficient learning successes). [12] Hence, here we experience a popular example for the convergence of digital and social marketing techniques.

\section{3) Marketing Intelligence as Social Media Marketing and (Micro) Targeting Tools}

There are many more digital marketing techniques which use big data and lead to new interaction of marketing and customers: Social media describe a variety of online channels and platforms. They are able to facilitate collaborative creation and dissemination of information and provide the basis for social engineering techniques (see chapter III). They include forums and message boards, review and opinion sites, social networks, blogging, microblogging, bookmarking, and media sharing. [13]

From the marketing intelligence point of view, social media platforms are self-seeding data sources, as the users provide data by posts, share, likes, comments, photos etc.: "Every social media platform provides its own analytical data to help businesses make decisions about advertising spending and to help them choose their particular advertising tactics." [14] Social media metrics include the opportunities to identify audiences, emerging business relevant topics, brand perceptions, user attitudes and behavior, market segments etc. [13]

Targeting technologies, in collaboration with mobile technologies, enable marketers to identify and address specific customer communities and/or customers personally. This procedure is known as "mass customization" which refers to group-related or even individualized mass production: the individualized car, the personally branded chocolate or the personally configured sports shoe. That means the consequence of micro targeting is micro marketing. [15] In the specified application of geo marketing, micro marketing involves small segments, down to the personal level (segment of one).

As early as 1990, the growth of micro marketing was recognised, resulting from a fragmented society and increasingly saturated markets: "Consumers do not form a nationwide mass, but are a product of their region or neighborhood." [16] With mobile and sensor technology in particular, advertising posters can directly recognize and address the passing public, for example in shopping malls, in front of shop windows, in cinemas or at bus stops. Micro marketing is primarily implemented through mobile marketing and through location-based services. [17] McKinsey sees the micro-marketing strategy as a development with strong potential. [18] Hence, micro marketing is on its way to changing from a digital marketing technique to social engineering.

\section{4) Marketing Intelligence as Real-Time Marketing}

Big data is also associated with analysis, evaluation and (re-)action in real time, which is one of the core capabilities of digital marketing techniques. The term timely, in this case, represents the implementation within milliseconds thereby enabling marketing techniques: Real-time marketing is based on digitalized marketing processes. Streaming analytics is an identification of analysis methods for data streams in 
real time. [19] Its goal is to process real time data so quickly that the analyses are also available in real time, i.e. live. Streaming analytics systems must meet high demands with regards to the throughput speed of the data, in order to guarantee fast evaluations. Streaming analytics record the routines of credit card use in real time for example: When customers proceed to the checkout to pay at a supermarket, they slide their card through the card reader or place their order in the online shopping basket.

These live-features are new for traditional marketing as outbound marketing, as the technical possibilities of web solutions have increased the expectations of marketing: "Real-time Marketing depicts the realtime response to customer demand, which is technically representable with real-time advertising, real-time bidding (online auction prices for advertising) and other applications." [20]

Current applications of real-time marketing also include, for example social listening, i.e. the recording, analysis, and evaluation of posts, shares, and likes in social media to capture the mood and the opinion of the media as a form of real-time marketing research. In addition, advertising and ad placement proceed live: real-time bidding similar to an auctioneering principle for determining the price of advertising space as well as recommendation marketing and dynamic pricing are examples of real-time marketing as a digital marketing technique. The consequences of real time abilities are to be shown later, when marketing intelligence is discussed as social engineering (see chapter III.2).

\section{5) Marketing Intelligence as Recommendation Marketing and Dynamic Pricing}

Product recommendations, which are determined on the basis of the data of user behavior of online shop visitors, are already used particularly frequently. Recommender systems are intended to reduce the complexity of the choice process. They generate personalized predictions about product liking, by filtering the past behavior and preference statements of consumers. [21] The social engineering technique, where trust is exchanged for reputation, became a digital version known as digital recommendation marketing, so that digital techniques and social measures are able to become two sides of the same marketing coin.

Another technique with which to use digital customer data are automated price adjustments. "Dynamic price adjustment is common practice on the web. Amazon is considered a pioneer in that regard. The mail-order giant changes its prices countless times a day. Users accept this as long as the offer and service are right." [22] The approach of multiple price changes per day is also known in the offline world: for example, in petrol stations. In the course of cross-channel marketing, i.e., the product and price policy integrated across channels, retailers will increasingly adapt their prices to developments on the internet in the real world as well. In consumer electronic stores, for example, digital price tags are increasingly being placed on shelves to serve this development. Hence, marketing intelligence impacts marketing decisions here and they in turn impact customer decisions. Therefore, we experience a snapshot of an evolving digitized-social system that impacts itself here.

\section{6) Marketing Intelligence as Mobile and Proximity Marketing}

Mobile devices, especially the smartphone, accompanied by the semantic web (web 3.0) enable web-based services to interact by voice recognition with web users and made marketing mobile. The mobility itself is not new: Listening to the radio has also migrated out of the home, as consumers are used to listening to radio in their cars. [23] What is new in the digitized marketing era is contentspecific, individualized, visual and/or conversational and geo-located marketing, and thus customized to-one-marketing, as smartphones are usually equipped with GPS (global positioning system). Digital mobile devices enable marketers to provide digital location based services. [24] This development marks a paradigmatic technological shift in marketing, sometimes characterized as a "mobile revolution". [25] Marketing began to individually accompany the customers almost everywhere: in the car, at work, in the restaurant, into the fitness club etc. Thus, mobile (social media) marketing is the digital platform for influencer marketing (see chapter III.2) and a source of big data.

Proximity technologies can automatically analyze significant touchpoints as parts of the customer's journey, which are both social engineering techniques (see chapter III.5). Nearfield communication (NFC) is an important service and at the same time, an important data source for the requirements of proximity marketing. NFC is a further development of RFID (radio-frequency identification). This is a radio standard for wireless data transmission, which is the communication between two elements e.g., mobile phone and cash register, located close to each other. This technology handles the interaction between the customer's smartphone and the point of sale. [24] Accordingly, proximity technologies frame the backbone of mobile touchpoints within the customer journey (see chapter III.5).

\section{7) Marketing Intelligence as Semantic Marketing}

"The arrival of the Semantic Web represents a revolution for the form of access and storage of information." [26] From a marketing strategic point of view, a crucial change from web 2.0 to web 3.0 is the recognition of "meaning". "The benefit of adding semantics consists of bridging nomenclature and terminological inconsistencies to include underlying meanings in a unified manner." [26] Also, voice recognition technologies of the smartphone or in the car depend on the ability of semantic technologies.

A central popular function of the semantic marketing became chatbots, a blending of words derived from "chat" for conversation and "bot" for robots. Chatbots as voice robots interact with people using spoken or written text. In the messenger service, they enable direct offers in the context of a chat or a message. These are virtual assistants as computer-based, virtual conversation partners or more precisely: intelligent voice-controlled applications, e.g. search or purchase services by voice. They belong to the so-called semantic web, i.e., "Web $2.0+$ artificial intelligence". [27] Until now, chatbots have mostly been using stored language rules or FAQs (frequently asked questions) in the form of databases that reacted to certain rules, such as keywords. Questions were categorized, and corresponding answers were prioritized. In the meantime, there are also chatbots who learn independently via machine learning. They have artificial intelligence and can learn semantics in the respective context of conversations and are thus a part of marketing intelligence. This development is based on four pillars: artificial intelligence, speech recognition technology, messaging services, and virtual assistants. [28] Chatbots and open API are two integral parts of conversational commerce [29]: Open API (application programming interface) are open programming interfaces which allow external providers to integrate content and services into the messaging app. Data can thus be exchanged and processed barrierfree without the user having to switch to another application or install additional apps. The internet, thus, becomes an essential tool for finding out what is happening at the moment, what the competition is doing, what customers are demanding, or even discovering technological trends, innovations and expert opinions. [30]

\section{8) Marketing Intelligence as Predictive Marketing}

Predictive intelligence is a method for machine learning, which is already known from image and face identification as well as speech recognition and language translation and is now finding its way into digital marketing. For example, insurance companies calculate potential predictors for driving safety by determining a person's age, gender and driving experience, e.g. derived from the geo data of drivers, which 
foreshadows the rising meaning of mobile technologies ("mobile first"). From this, the insurance company then determines the probable risk of accident and the amount of motor vehicle insurance. Predictive pricing will probably become more and more popular especially in the context of customized mass services.

The "predictive" approach initially is nothing new, not even in marketing, if one thinks of the fields of action of marketing and trend research, which always include prognostic tasks. What's is new however, is the fact that today there are standard technologies and applications on the market which can also be used by companies without data scientists, market researchers or software programming. [31]

\section{9) Marketing Intelligence as Touchpoint Marketing and Marketing Automation}

Customers leave digital data: from shares, likes, and posts, for example, to a branded product, from the search behavior in the shop, to payment transactions or cancellations and mobile movement in shopping malls and/or the point of sales. The analysis of customer retention times, search paths, contact points, queues at checkouts also make proximity marketing a field of action for marketing intelligence to derive assortments, shelf campaigns, check out openings or newly arranged product presentations from. For example, the longer a customer stays in a certain zone of a store or the customer heading for goods islands, info counters or departments, etc. can be interpreted as "exploration" of the goods on offer presented there. Proximity can support every touchpoint, from the first perception of a product in the shopping street, to evaluation, purchase, repurchase, and recommendation. Digitalization of marketing processes implicates the digitalization of touchpoints, i.e. interfaces between customers and products or services, which frame customer decisions. [32]

The opportunity of touchpoints within the customer journey leads to the integrated digital marketing automation. [33] The core value of automation is the repeatability of digital marketing measures in which people do not have to intervene. "What does automation mean to marketing people? (...) New methods of automation will make marketing information available much faster than before and provide data that was not available before." [34] What sounds like a rather recent statement is a quote from the 1960s. It shows that marketing has always included an attempt at standardization. This foreshadows for example the term programmatic advertising. It describes the datasupported trading of online advertising spaces. Campaigns can be booked fully automatically and can thus be adapted in real time to the situation of (mobile) users. Campaigns and messages can be adapted in real time to the needs and communication channels of consumers. [35]

\section{B. Summarizing Discussion}

Looking back upon the selected digital marketing techniques described above (see summarizing Table I.), it is ultimately the search engines and, in this case, big data in the form of data on the search behavior of internet users, that are driving the current significance of content marketing and inbound marketing, as the methodical marketing discussion below will show.

The open question is, in how far these digital techniques become marketing practice. To answer this question this paper focuses in the following on currently utilized marketing practices. This resorts to the digital marketing techniques as applied social engineering.

\section{Marketing Intelligence as Social EngineERING}

\section{A. Introduction of Marketing Intelligence from a Social Engineering Point of View \\ "Technology is changing the context of and practice of marketing."}

[37] Currently marketing practices are experiencing the shift from "big data to big impact." [38] Applied marketing practices can be interpreted as social engineering. Social engineering is frequently discussed and often associated with negative, often politically motivated interventions impacting individual behavior. In contrary, sometimes social engineering is something positive, e.g. if it is seen as a kind of art: "Social engineering is the art of getting users to compromise information systems." [39] Therefore, marketing intelligence becomes "artificial intelligence", not just in a digital, but also in a social sense. A variety of definitions of social engineering exist and certain elements are agreed upon. One of these agreed aspects is that social engineering means a set of applied methods for social impact and thus, social change. [40] This means that social engineering are practices applied to influence people. Hence, marketing, PR-management, advertising etc. are examples of social engineering.

In the following, methodical shifts in marketing are identified. For this purpose the described marketing techniques above are used as applied social engineering. It will be discussed that this also leads to methodological shifts in marketing. Above all, search engine marketing technology emphasizes the current importance of inbound marketing as a method of market cultivation. This is in contrast to outbound marketing, which has long made the product the most important $p$ in the marketing mix. However, from a current perspective, customer needs should stand in the center of this view as a methodical paradigm, if one regards customer management and customer relationship management as a central field of action in marketing.

\section{1) Marketing Intelligence as Content Marketing}

Content marketing is teeming with marketing measures to generate and provide content. As the expression "social media" emphasizes, these media are "social". Of course, every used media is "social" as they are social phenomenon. But in contrast to TV, radio or the press just the social media are explicitly named "social". Classic media and social media obey distinctive logics. Mass media provide a flow of topics by organizing linear programs to gain attention. [41] The key factor for the success of social media is not just transmitting information, but conversation and, thus, interaction. "Social media is not only a place to market the products and services of a company, but also a place to interact with the customers". [42] Hence, the logic of classic media obeys an inside-out approach by transmitting information to gain attraction in contrast to the logic of social media, which concept is configured "outside-in" on the basis of conversation in order to gain interaction.

If we trace the evolution of social media, we currently experience a transformation process within (online) marketing across media. Traditionally marketing had been placing ads to gain attraction. This manner of "paid media" is also to be found in social media. But from the user's point of view, social media becomes attractive because of its interesting, entertaining and sharable content. This content is the basis for so called "viral processes". As soon as these social interaction-processes become vivid, these media are used to call "earned media" as far as a specific brand, product or corporation is subject of the viral processes. The ownership of content is the corporation and/or the recipient. Thus, viral effects within social media are known as "earned media" as they are distributed at no direct cost to the corporation. [43] "Sharing online content is an integral part of modern life." [44] To achieve viral effects, studies suggest providing content which activates and evokes emotions because such content is likely to be shared. [44] Thus, we experience a transformation process of marketing. [45] Today social media is recognized as a hybrid element of the promotion mix: In a traditional sense, it enables companies to talk to their customers. In a nontraditional sense, it enables customers to talk directly to one another. [46]

While classical marketing instruments draw the attention of consumers to the product directly, content marketing focuses more on 
TABLE I. Popular digital Marketing Techniques

\begin{tabular}{|c|c|}
\hline Marketing intelligence & Idea \\
\hline $\begin{array}{l}\text { Big data or data driven } \\
\text { marketing }\end{array}$ & $\begin{array}{l}\text { Big Data or data driven marketing is the systematic alignment of marketing measures with a digitally recordable target, } \\
\text { process, and data result, as well as the corresponding analysis results based on digital data. }\end{array}$ \\
\hline Search engine marketing & $\begin{array}{l}\text { - Placing contributions in the search results of search engines such as Google as high up as possible. } \\
\text { - Since Google has a market share of over } 90 \text { percent, search engine marketing is currently actually google marketing. }\end{array}$ \\
\hline $\begin{array}{l}\text { Social media marketing and } \\
\text { personalization }\end{array}$ & $\begin{array}{l}\text { - Social Media as big data sources. } \\
\text { - Social media data as a digital farm seeded by the users themselves. } \\
\text { - Personalization is the adaptation of information, services or products to the defined or presumed needs of a person. The } \\
\text { adaptation can take place on the basis of the person's profile, the current situation of the person, but also through active } \\
\text { "personalization" by the user. [36] }\end{array}$ \\
\hline $\begin{array}{l}\text { Mass customization and } \\
\text { (micro-) targeting }\end{array}$ & $\begin{array}{l}\text { - Targeting means the formation of target groups through (market) segmentation. On the basis of the evaluation of mass } \\
\text { data, it deviates from conventional target group formation. } \\
\text { - Micro-targeting as big data targeting or data-based marketing refers to the evaluation of large amounts of data, the } \\
\text { definition of special target groups and, in marketing, the (quasi-) individualized approach to each individual customer } \\
\text { with personalized advertising content. }\end{array}$ \\
\hline Recommendation marketing & $\begin{array}{l}\text { - Simple recommendation systems already work when a webshop operator simply stores a number of products as } \\
\text { recommendations when visitors search for certain other products in his shop. } \\
\text { - Marketing intelligence refers to recommendations that are based on the analysis of mass data. }\end{array}$ \\
\hline $\begin{array}{l}\text { Mobile and proximity } \\
\text { marketing with location } \\
\text { based services and nearfield } \\
\text { communications }\end{array}$ & $\begin{array}{l}\text { - Proximity communication refers to the part of mobile corporate communication or product communication at the location } \\
\text { of a company, e.g., in retail outlets, shopping malls or stadiums. } \\
\text { - Location based services (LBS) are applications of mobile commerce that generate added value for the user through } \\
\text { localization. Here, a combination of mobile image management and marketing with call-to-action, i.e., appeals for action } \\
\text { such as the redemption of discounts, takes place. } \\
\text { - Nearfield communication (NFC) enables services as cashless payment. }\end{array}$ \\
\hline Semantic marketing & $\begin{array}{l}\text { - Voice recognition systems enable digital conversation. } \\
\text { - Web 3.0 as semantic web enables real time conversation. }\end{array}$ \\
\hline Predictive marketing & $\begin{array}{l}\text { - Predictive marketing depicts the application of analytics to calculate probabilities of occurrence of events and the } \\
\text { application of marketing measures from them. } \\
\text { - Predictive analytics is a method used to identify recurring patterns in data and then use sophisticated algorithms to } \\
\text { predict their future development, e.g. with predictive prices. }\end{array}$ \\
\hline
\end{tabular}

publishing by sharing media content. From a methodological point of view, the term content today thus stands less for information, but for "edutainment" i.e., appealing, playful and entertaining communication to trigger viral effects, especially in social media. With regard to implementation, this refers to the preparation of former advertising messages in the form of texts, images or videos, which are intended to increase awareness regarding the special interest of website visitors. The classic advertising marketing communication ("appeal to buy") is currently considered unsuitable here.

\section{2) Marketing Intelligence as Inbound Marketing and Soft Selling}

Studies reveal the effect "from social to sale" or with other words from "hard to soft selling": "The clear messages from our study are that social media marketing matters and that managers should embrace it to communicate and nurture relationships with customers." [47] Marketing intelligence emphasizes the trend of inbound marketing. It is closely linked to content marketing, as social media marketing does not tolerate direct appeals to buy. "Blogs as a tool for digital marketing have successfully created an impact for increasing sales revenue, especially for products where customers can read reviews and write comments about personal experiences." [3]

The current prominence of content marketing is a result of (mobile) marketing intelligence. Instead of keyword management for search engine optimization, content is important nowadays. Companies that engage in search engine marketing are dependent on content to ensure that search engines display their sites as high up in the hit lists as possible. Hence, online marketing as search engine marketing triggers a new technique of social engineering: digital inbound marketing. Instead of interrupting advertising, it is based on interactivity and commitment, i.e., pull marketing, as it relies on the initiative of interested parties. Here the currently popular role of influencer marketing within social media marketing should be mentioned. For marketing, this means considering four fields of action: content provision, search engine optimization, social media marketing and brand-oriented marketing communication. [48]

The mobile and customized technology driven opportunities are also a precondition for the rise of inbound marketing, as many customer decisions are made whilst out and about. "Mobile advertising seems to have raised considerable interest as mobile technology has advanced." [49] Mobile micro marketing and recommender marketing offer the ability to react in real-time. This real-time competence is reinforced 
by the expectations of social media users, who expect timely (re-) actions from companies. Here we experience the interdependency of the technological and shifts in applied marketing communications becoming not just a social engineering technique, but having a culturalsociological impact: Social Media shapes the generation $\mathrm{Z}$ and thus its customer behavior ("generation facebook"). [50] Mobile phones and social media are two examples of big data farms steadily seeded by the users. Taking the meaning of content and/or social media marketing as a given, some argue that traditional marketing is no longer a viable option as it works with push messages in line with traditional transaction marketing. [48]

\section{3) Marketing Intelligence as Creative Marketing}

The meaning of content marketing leads to the impetus for creative marketing driven by marketing intelligence, as well as the consequences for automation and evaluation.

Events such as the Marketing Convention 2016 in Munich titled "Man or Machine: Marketing between Creation and Automation" [51] addressed the problem of the potential for standardization and automation, juxtaposed with the individualization and service potential of digitalization: on the one hand, the potentials are emphasized from a marketing perspective with cost savings, through standardization by automation. On the other hand, there is new potential for success through creativity, new products, and services, such as the aforementioned fraud warning for bank customers, based on the evaluation of transaction anomalies.

Creativity can be described as the creation of new and useful ideas. From a results perspective, creativity can mean new products and services, so that creativity leads to innovation and at the same time, can just be creativity. Creativity is thus defined both as a characteristic and a process, but also in terms of the environment, culture or results. [52] From the perspective of marketing intelligence, it can be used wherever people come together with their mobile phones and thus generate data for creative potential. Accordingly, marketing intelligence is addressed as collective intelligence for solving creative problems. [53]

As mentioned above, the digital technique "targeting" stands for the digital search with the aim of addressing customers, with the targeted control of mobile and situation-dependent identification of context-dependent target groups. It enables location-dependent communication: Advertising for the same brand in the respective context of the location, for example, sports advertising in stadiums or taxi advertising after busses have been delayed and the delay has been digitally recorded online by the local transport companies. Another opportunity for creative communication is provided by weatherdependent communication: the department store's umbrella advertising for globetrotters in the shopping mile, the wellness hotel's discount campaign for North Sea vacationers whose holiday season is cold and wet. This (creative) potential is supported above all by mobile devices (i.e., such as notebooks, smartphone/-watch, tablets) and/or other specific media (such as connected car, social media, displays) as mentioned above, when mobile marketing was introduced.

Mobile marketing intelligence is also understood as the art of creating attractive customer experiences at the right time: a new marketing capability with digital data for digital communication channels. [54] Creative marketing combines creativity with innovation [52] by also including the crowd as creative potential in value creation. This foreshadows the opportunities of innovation by creativity.

\section{4) Marketing Intelligence as Innovation Marketing}

Marketing intelligence is considered to have great potential in the development of new products and services and is labeled as open source intelligence. [55] Accordingly, many terms are entwined around digital innovations and product developments, which are referred to as data- driven innovation, user-driven innovation, event-driven innovation or social $r \& d$ (social research and development). With the combination of more competence regarding technological data analysis and interaction orientation, a study of around 150 US companies by Trainor et al. showed that both relationship orientation and marketing intelligence competence have a positive influence on new product development. [56] Of course, these innovation approaches don't necessarily need big data or intelligence to operate. But the more data is available to support innovation, the more useful insights may be identified, e.g. with the evaluation of data as portals for product improvement, data of crowdsourcing for the development of new ideas by the community etc.

\section{5) Marketing Intelligence as Customer Journey Marketing}

The customer journey describes the journey of a potential customer through various contact points (so-called "touch points") with a product or service, a brand or a company, from inspiration and the realization of needs, to the procurement of information, search and final action. It could be seen as an enlarged customer decision process.

The social engineering technique arising from the mainly digital shaped touchpoint management is frequently named as the customer journey. The social relevance of the customer journey becomes very obvious when it differentiates between brand owned, partner owned, customer owned and social/external owned touchpoints. [54] It is intensively dealt with, especially in online and mobile marketing, but also includes the offline world.

The customer journey in online marketing is preferable to digital marketing because it is particularly easy to measure the success of established contact points with tracking technologies, by investigating the click and search behavior of internet users. But the "dichotomy of online-offline" today largely is outdated. Instead, the mapping of touchpoints is yet to be examined in the light of consumer decisionmaking, i.e. the integration of relevant channels is crucial to understand customer shopping behavior. [57]

\section{6) Marketing Intelligence as Conversational Marketing}

The touchpoint voice will develop into a central data source in marketing. Some experts are talking about a voice first revolution i.e., in addition to "mobile first" give way for voice services. [58] This development leads to conversational commerce, i.e., to conversationbased commerce, which leads particularly to the extension of web 3.0. The term conversational commerce is partly attributed to Messina, who already used this term in 2015 and declared 2016 as the year of conversational commerce. [59] [60] However, the term "commerce" does not go far enough because service marketing, in particular, is benefiting from this development.

"Instead of tormenting themselves on their PC at home with ordering and payment processes, customers will soon be booking flights, ordering food, ordering concert tickets or buying shoes via voice control on their smartphone. What's more, they will also use their messaging app to process claims, make use of services and receive real-time advice: Conversational Commerce, customer interaction with the help of artificial intelligence." [29] In essence, conversational marketing is a language-based development of dialogue marketing in the sense of long-term customer interaction. [61]

\section{7) Marketing Intelligence as Customized Lifecycle Marketing}

The life cycle model is often found in marketing: Companies, products, customers - they all go through lifecycles, derived from the biological processes of existence. Subject to the regarded stage of the cycle, corresponding marketing action is to be applied. In contrast to the product lifecycle, the customer lifecycle emphasizes the individual customer approach. While the product life cycle, which is often contained in conventional marketing textbooks, follows standardized mass marketing, the customer life cycle emphasizes individual, 
personalized customer interaction.

Big data supports the understanding of customers' life cycle and behavior. "Customers voluntarily generate a huge amount of data daily by detailing their interest and preference about products or services to the public through various channels." [62] Profiling for customers becomes important for business to make sure that the whole CRM life cycle (sales, marketing, and customer service) is offering personalized and customized services, so that each customer will have a different experience according to their needs and interest. [62]

Lifecycle marketing is also known as a field of action in CRM. Its goal is to build long-term customer loyalty to the company and its employees by considering the various specific life situations and phases of the customers. [63] "CRM represents (...) in relation to the customer markets a radical departure from the classical marketing concept, which in the sense of effective sales management has a very strong instrumental function regarding the dominance of product and communication." [63]

\section{8) Marketing Intelligence as Performance Marketing}

The creative potential of big data mentioned above methodically stands in contrast to the approach of performance marketing: With the current significance of content marketing, one could assume that soft goals such as web authority, i.e., the resonance through linking, commenting, etc. of the community, would become the focus of marketing intelligence. At the same time however, the ability to measure the performance of marketing rises. For example, digital campaigns with multivariate analysis methods and experimental research designs can be used to determine which dimensions make them particularly successful. For example, in terms of customer value along the life cycle of Search Engine Marketing at Google. [64]

(Digital) key performance indicators are gaining new attention, as marketing is coming under pressure to succeed. [65] "Marketing practitioners are under increasing pressure to demonstrate their contribution to firm performance." [66] Studies reveal that some companies emphasize short-term financial metrics at the expense of measuring long-term impacts. [67] "Performance Marketing in its purest form is purely success-oriented. Successful campaign modules (texts, keywords, tools, advertising media) are accelerated and expanded. Less successful ones are optimized and eliminated if the defined goals are still missed." [68] As creativity or content belong to the idea of inbound marketing or "soft selling" a conceptual gap of measuring success arises between Marketing 1.0 and Marketing 4.0.

\section{9) Marketing Intelligence as Marketing 4.0}

Following the development of industry 4.0 with the networking of man and machine, a marketing 4.0 debate is taking place on the performance and cost-effective availability of (mobile) internet. Looking back, this debate shows a development that focuses on human-centric development through digitalization: [69]

- Marketing 1.0: The origin as a prototype puts the core competence of Marketing on a product and its distribution. Marketing activities are geared towards this, so that the market is at the center.

- Marketing 2.0: The focus shifts to the consumer. Companies further differentiate from each other as consumers become more self-confident (from the 1970s).

- Marketing 3.0: The focus is on people. They are determined by values that depend on their environment. Customer management instead of market-oriented corporate management is prevalent, as human centricity characterizes Marketing (from the 1980s onwards).

- Marketing 4.0: The focus here is on digitalization and thus the convergence of technologies, without losing sight of the previous stage. This means an online-offline integration (from approx. 2010 onwards).

The evolution of marketing will continue. The next version, Marketing 5.0, already is in discussion.

- Marketing 5.0: Expectations regarding further developments include current popular discussions like block chain and platform marketing as a part of the blockchain economy. [70] Analogue to the backbone of bitcoins block chain will provide marketing services which depend on the trust provided by closed IT systems, which are worthy e.g. for guaranteeing selected target media of programmatic advertising or to avoid fake accounts in social media. So, marketing 5.0 will probably be the epoch of digital trust marketing.

\section{B. Summarizing Discussion}

Whether or not the concept and terminology of marketing intelligence, as smart data marketing on an IT basis, will hold its own or prevail is currently rather doubtful due to its technical-analytical past. It will presumably be absorbed in a multitude of possible

TABle II. Marketing: Popular Social Engineering Techniques

\begin{tabular}{|l|l|}
\hline \multicolumn{1}{|c|}{ Marketing intelligence } & \multicolumn{1}{c|}{ Idea } \\
\hline Content marketing & $\begin{array}{l}\text { Content marketing refers to the informative, consultative and/or entertaining provision of company information with } \\
\text { the goal of making them deal with information in the first place. }\end{array}$ \\
\hline $\begin{array}{l}\text { Inbound marketing/ Influencer } \\
\text { marketing/social media marketing }\end{array}$ & $\begin{array}{l}\text { • Pull marketing as inbound marketing (outside-in thinking). } \\
\text { • The content especially of social media users impact the rules of marketing wording: the shift from hard to soft selling. }\end{array}$ \\
\hline Creative marketing & Marketing intelligence is addressed as collective intelligence for generating creative solutions. \\
\hline Innovation marketing & Open source intelligence as the source of the development of new products and services. \\
\hline Customer journey marketing & $\begin{array}{l}\text { Marketing impacting the journey of a potential customer through various contact points (so-called touch points) with a } \\
\text { product or service, a brand or a company. }\end{array}$ \\
\hline Conversational marketing & The current voice first revolution as an addition to the new mobile paradigm. \\
\hline Customized lifecycle marketing & $\begin{array}{l}\text { • Product life cycle follows standardized mass marketing. } \\
\text { - Customer life cycle emphasizes individual, personalized customer interaction. }\end{array}$ \\
\hline Performance marketing & $\begin{array}{l}\text { Performance marketing refers above all to digital marketing measures and processes relating to online and mobile } \\
\text { marketing measures, which can be particularly well measured and thus optimized. }\end{array}$ \\
\hline Marketing 4.0 \& 5.0 & $\begin{array}{l}\text { • Value based marketing (3.0) and digital marketing (4.0). } \\
\text { • Trust marketing (5.0) on the basis of closed systems like block chains. }\end{array}$ \\
\hline
\end{tabular}


applications of marketing as social engineering techniques (see above/ see summarizing Table II).

Regarding the shift of marketing methodology is to state: If the prototype marketing with marketing 1.0 consists of sales-related massmarket orientation, then marketing is originally characterized by the methodological paradigm of inside-out. [71] The methodical approach is based on product solutions that open up markets. This is another reason why the product mix is regarded as the "heart of marketing" [72] In fact, marketing goes back to consumer goods marketing and thus to mass markets. The classic $4 \mathrm{P}$ marketing mix also shows that the original marketing did not focus on the customer. [73] Interestingly enough from today's point of view, neither the customer nor the salesperson is originally considered in the conventional marketing mix, but instead places the product at its center. This inside-out approach was later criticized as being too narrow, and Hunt's Nature of Marketing added a micro-macro-approach [74] or stakeholders beyond markets respectively [75]. Marketing 3.0 focuses on the values of customers also beyond markets, hence, they converge with "soft selling" approaches, which are more subtle and indirect than the traditional marketing sales. [76] "Soft selling" became the paradigm to gain earned media.

\section{Conclusion: Marketing Intelligence as a Shift From Digital Marketing Techniques to Social Engineering}

Looking back and summarizing the evolution of digital marketing, we arrive at a multiplicity of "marketing-as..."-landscape. Table I to III retrace how marketing intelligence already has started to impact marketing practice with a big scope of social engineering techniques (see Table III).

TABLE III. The Landscape of Digital Marketing Techniques and Digital Marketing as Social Engineering

\begin{tabular}{|l|l|}
\hline \multicolumn{1}{|c|}{$\begin{array}{c}\text { Marketing as } \\
\text { digital techniques }\end{array}$} & \multicolumn{1}{c|}{$\begin{array}{c}\text { Marketing as } \\
\text { social engineering }\end{array}$} \\
\hline - Big data or data driven marketing & \\
- Search engine marketing & \\
- Social media marketing and & • Content marketing \\
personalization & - Inbound marketing/ influencer \\
- Mass customization and (micro-) & marketing \\
targeting & • Creative marketing \\
- Recommender marketing & • Innovation marketing \\
- Dynamic pricing & • Customer journey marketing \\
- Mobile and proximity marketing & • Conversational marketing \\
with location based services and & • Customized lifecycle marketing \\
nearfield communications & • Performance marketing \\
- Semantic marketing & • Marketing 4.0 \& 5.0 \\
- Predictive marketing & \\
mouchpoint marketing and & \\
\hline
\end{tabular}

Content marketing, for instance, today wouldn't be so successful without the capability of search engine on the basis of big data-analysis. Of course, marketing had been benefiting from other techniques also before the beginning of digitalization, as the discussion of marketing automation in the 1960th shows (see above, chapter II.9). Nevertheless, this contribution focuses on the current shifts driven by digitalization.

Marketing intelligence has long since led to a paradigm shift in marketing, with the described digital techniques shifting to the social engineering techniques - even for companies that are not actively involved in big data initiatives. If companies aim to be listed high up on search engine search results, they need interesting content from the point of view of internet users. This outside-in methodology is the top of the paradigm shift in marketing methodology. Thus, we are currently experiencing another methodical shift. "When people say, 'There is a method to this', it is usually supposed to mean 'systematic approach." [77] The term method thus refers to formative paradigms and principles as a cross-instrument approach to achieving specific goals. Methodology characterizes the totality of methods. The term method (from Greek methódos = way of proceeding) describes the way of thinking and recognizing. [77]

- Methodological paradigm shift: Originally, marketing was solely sales-, product- or market-oriented, i.e., Marketing 1.0 and 2.0 followed the inside-out perspective. In inbound marketing, which from the company's point of view is considered a passive approach, the initiative comes from the customer who is actively establishing contact with a company. [61] With Content Marketing, on the other hand, the inside-out perspective has been supplemented by the outside-in perspective. This type of marketing is actually $P R$ management, in that appeals to buy are inadmissible and instead entertainment-centric, humorous, target-group-oriented content is demanded by the stakeholders. [77] It is currently unclear whether and how intensely this paradigm shift will shape offline activities as well. One could now jump to the conclusion that customer needs and the value orientation of marketing 3.0 have won (see Table IV). - However, this would be an incorrect assumption, as so-called performance marketing is also being introduced at the same time within marketing 4.0: This refers to data-supported and automated digital marketing as a particularly efficient form of marketing. With marketing automation as a marketing technique, it can be assumed that many services will fall victim to the superficial measurement of marketing efficiency. At the same time, however, big data marketing will also create new creative potential. The integration of customers into value creation is not new if one thinks of furniture giant Ikea, which leaves the final assembly of their products to their customers. But the multitude and bandwidth of interactive marketing leads to cooperative added value: the evaluation of orders and customer wishes for the development of individual order options for otherwise standardized products and/ or services up to the so-called customer as co-designer of the fast food menu or sneaker.

TABLE IV. Methodical CoRnerstones of Outbound and InBound MARKETING [78]

\begin{tabular}{|l|l|l|}
\hline Key Points & Traditional Marketing & \multicolumn{1}{|c|}{ Inbound Marketing } \\
\hline Basis & Interruption & Organic Interaction \\
\hline Goal & $\begin{array}{l}\text { Interaction as new } \\
\text { customer acquisition } \\
\text { through short-term sales } \\
\text { increases }\end{array}$ & $\begin{array}{l}\text { Interaction as requests } \\
\text { from new interested } \\
\text { parties for the } \\
\text { development of long-term } \\
\text { customer relationships }\end{array}$ \\
\hline Method & $\begin{array}{l}\text { Push Marketing as } \\
\text { Outbound Marketing } \\
\text { (inside-out thinking) }\end{array}$ & $\begin{array}{l}\text { Pull Marketing as Inbound } \\
\text { Marketing (outside-in } \\
\text { thinking) }\end{array}$ \\
\hline Target & Mass markets, groups & Fans, indivdual \\
\hline Location & At home & At home and mobile \\
\hline Time & $\begin{array}{l}\text { Planning and approval } \\
\text { processes make marketing } \\
\text { slow }\end{array}$ & $\begin{array}{l}\text { This real-time competence } \\
\text { is reinforced by the } \\
\text { expectations of social } \\
\text { media users, who expect } \\
\text { timely (re-)actions from } \\
\text { companies. }\end{array}$ \\
\hline Instruments & Conventional advertising & $\begin{array}{l}\text { Blogs, viral } \\
\text { communication, etc. }\end{array}$ \\
\hline Sales approach & Hard & Soft \\
\hline Marketing X.0 & Marketing 1.0 \& 2.0 & Marketing 3.0 \& 4.0 \\
\hline
\end{tabular}

- Technical paradigm shift: Digital marketing based on big data 
is more than just a multitude of digital marketing tools. Real-time marketing with its emphasis on reaction speed and digital marketing processes - from search to purchase - can be implemented automatically along the customer life cycle. Thus, process-related marketing automation takes place: Automated, cross-channel campaign management in real time and/or along a customer's life cycle by addressing the customer through cloud marketing via e-mail, WhatsApp, banner advertising on the Web or smart TV advertising along the customer journey. It is even possible to use micro marketing with market segmentation at the individual level. This can be realized in real time as proximity marketing of the retail branch, and thus describes the part of the mobile, corporate or product communication in or at the location of a company, for example in the retail trade, at the shopping mall or the football stadium. This also includes, for example, price communication, in other words, the evaluation of the search behavior for price setting depending on the online search profile of the passing customer.

- Cultural paradigm shift: Some experts pretend that with the availability of powerful data analysis technology, simplified (marketing) decisions are also available. In fact, data dissemination, the dissemination and availability of smart data, is likely to be a critical point for the success of marketing intelligence applications. The basis and consequence of this is a corporate culture which first turns to these technical innovations. Intelligence dissemination must, however, be organized. Contact management between data managers in marketing and those who can and should use their data - for example in sales, distribution or purchasing - is only one source of potential success. [79] Success in marketing intelligence is therefore also dependent on internal company social networking. In this respect, big data marketing requires a datarelated knowledge culture in many companies.

\section{REFERENCES}

[1] A. Amado, P. Cortez, P. Rita, and S. Moro. (2018), "Research trends on Big Data in Marketing: A text mining and topic modeling based literature analysis", European Research on Management and Business Economics, Volume 24, Issue 1, January-April 2018, pp. 1-7, doi: doi.org/10.1016/j. iedeen.2017.06.002

[2] Y. Durmaz, I.H. Efendioglu (2016), “Travel from Traditional Marketing to Digital Marketing", Global Journal of Management and Business Research: E-Marketing, Volume 16 Issue 2, pp. 35-40.

[3] M. Bala, D. Verma (2018), "A Critical Review of Digital Marketing", International Journal of Management, IT \& Engineering, Vol. 8 Issue 10, October 2018, pp. 321-339.

[4] W.T. Kelley (1965), "Marketing Intelligence for the Top-Management", Journal of Marketing, Volume 29, October, pp. 19-24.

[5] S. Fan, R.Y.K. Lau, and J.L Zhao (2015), "Demystifying Big Data Analytics for Business Intelligence Through the Lens of Marketing Mix", Big Data Research, 2, pp. 28-32, doi: dx.doi.org/10.1016/j.bdr.2015.02.006.

[6] P.R. Prabhaker, M.J. Sheehan, and J.I. Coppett (1997), "The power of technology in business selling: call centers", Journal of Business \& Industrial Marketing, Vol. 12 Issue: 3/4, pp. 222-235, doi: doi. org/10.1108/08858629710188054.

[7] M. Hartemo (2016), "Email Marketing in the era of the empowered consumer", Journal of Research in Interactive Marketing, Vol. 10, Issue 3, pp. 212-230, doi: doi.org/10.1108/JRIM-06-2015-0040.

[8] P.V. Jenster, K. Solberg Soilen (2009), Market Intelligence: Building Strategic Insight, Gylling, Copenhagen Business School Press, Narayana Press.

[9] A. Amado, P. Cortez, P. Rita, and S. Moro. (2018), "Research trends on Big Data in Marketing: A text mining and topic modeling based literature analysis", European Research on Management and Business Economics, Volume 24, Issue 1, January-April 2018, pp. 1-7, doi: doi.org/10.1016/j. iedeen.2017.06.002

[10] C. A. Brea (2012), "Pragmalytics: Practical Approaches to Marketing Analytics in the Digital Age”, Bloomington, iUniverse.
[11] P.K. Kannan, H.A. Li (2016), "Digital Marketing: A framework, review and research agenda", International Journal of Research in Marketing, 34, 2017, pp. 22-45, doi: 10.1016/j.jiresmar.2016.11.006.

[12] Y. Yuniarthe, (2017), "Application of Artificial Intelligence (AI) in Search Engine Optimization (SEO)", International Conference on Soft Computing, Intelligent System and Information Technology, pp. 96-101.

[13] U. Ruhi (2012), "Social Media Analytics as a Business Intelligence Practice: Current Landscape \& Future Prospects", Journal of Internet Social Networking \& Virtual Communities, pp. 1-12, doi: 10.5171/2012.920553.

[14] S. Lou (2017), "Applying Data Analytics to Social Media Advertising: A Twitter Advertising Campaign Case Study", Journal of Advertising Education, Vol 21, Issue 1, doi: doi.org/10.1177/109804821702100106.

[15] E. Sivadasa, R. Grewalb, and J. Kellarisc (1998), “The Internet as a Micro Marketing Tool: Targeting Consumers through Preferences Revealed in Music Newsgroup Usage", Journal of Business Research, Volume 41, Issue 3, March 1998, pp. 179-186, doi: doi.org/10.1016/S01482963(97)00060-X.

[16] S.L. Hapoienu (1990), “The Rise of MicroMarketing”, Journal of Business Strategy, November/December, pp. 37-42.

[17] L.M. Hilty, B. Oertel, M. Wölk, and K. Pärl (2012), "Lokalisiert und identifiziert: wie Ortungstechnologien unser Leben verändern”, Zürich, vdf. Accessed: May 2, 2019. [Online]. Available: https://files.ifi.uzh. ch/hilty/t/Literature_by_RQs/RQ\%20227/2012_Hilty_Oertel_Woelk_ Paerli_Lokalisiert_und_identifiziert_BUCH.pdf

[18] M. Goyal, M.Q. Hancock, and H. Hatami (2012), "Selling into Micromarkets", Harvard Business Review, July-August 2012, Accessed: May 2, 2019. [Online]. Available: https://hbr.org/2012/07/selling-intomicromarkets.

[19] C. Lanquillon, H. Mallow (2015) "Advanced Analytics mit Big Data", in: J. Dorschel (ed.), Praxishandbuch Big Data: Wirtschaft - Recht - Technik, Wiesbaden, SpringerGabler, pp. 55- 89.

[20] J. Lies (2017), "Die Digitalisierung der Kommunikation im Mittelstand Auswirkungen von Marketing 4.0", Wiesbaden, SpringerGabler.

[21] T. Hennig-Thurau, A. Marchand, P. Marx (2012), "Can Automated Group Recommender Systems Help Consumers Make Better Choices?”, Journal of Marketing, 89, Volume 76, September 2012, pp. 89-109, doi: DOI: $10.1509 / \mathrm{jm} .10 .0537$.

[22] A. Kalka, R. Krämer (2016), "Dynamic Pricing: Verspielt Amazon das Vertrauen seiner Kunden?", Absatzwirtschaft online, Accessed: May 2, 2019. [Online]. Available: http://www.absatzwirtschaft.de/dynamicpricing-verspielt-amazon-das-vertrauen-seiner-kunden-75271/

[23] S. Banerjee, R.R. Dholakia (2008), "Mobile Advertising: Does Location Based Advertising Work?", International Journal of Mobile Marketing, December 2008, Vol. 3, No. 2, pp. 68-74.

[24] G. Arcese, G. Campagna, S. Flammini, and O. Martucci (2014), "Near Field Communication: Technology and Market Trends", Technologies 2014, 2(3), pp. 143-163, doi:10.3390/technologies2030143.

[25] Y.B.B. Öztaş (2015), “The Increasing Importance of Mobile Marketing in the Light of the Improvement of Mobile Phones, Confronted Problems Encountered in Practice, Solution Offers and Expectations", World Conference on Technology, Innovation and Entrepreneurship, Procedia - Social and Behavioral Sciences, 195 (2015), pp. 1066-1073, doi: 10.1016/j.sbspro.2015.06.150.

[26] A.G. Crespo, R. Colomo-Palacios, J.M.Gómez-Berbis, F. Paniagua-Martín (2010), "Customer Relationship Management in Social and Semantic Web Environments", International Journal of Customer Relationship Marketing and Management, pp. 1-10, doi: 10.4018/jcrmm.2010040101.

[27] I. Sjurts (2011) (ed.), "Web 3.0", Gabler Lexikon Medienwirtschaft, Wiesbaden, Gabler.

[28] S. Tuzovic, S. Paluch (2018), "Conversational Commerce - A new area for Service Business Development," in: M. Bruhn, K. Hadwich (eds.): Service Business Development: Strategien - Innovationen - Geschäftsmodelle; Forum Dienstleistungsmanagement, Band 1, Wiesbaden, SpringerGabler, S. $81-100$

[29] K. Dörner, B. Hosseini (2016), “Conversational Commerce entwickelt sich zum Zukunftstrend - dank Messenger-Boom und Bots", McKinsey \& Company, Absatzwirtschaft, Accessed: May 2, 2019. [Online]. Available: http://www.absatzwirtschaft.de/conversational-commerce-entwickeltsich-zum-zukunftstrend-dank-messenger-boom-und-bots-89619/

[30] F.J. Garrigos-Simon, R.L. Alcamí, and T.B. Ribera (2012), "Social networks and Web 3.0: their impact on the management and marketing of 
organizations", Management Decision, Vol. 50 Issue: 10, pp.1880-1890, doi: doi.org/10.1108/00251741211279657.

[31] O. Artun, D. Levin (2015), "Predictive Marketing: Easy Ways Every Marketer Can Use Customer Analytics", Hoboken, Wiley.

[32] A. Følstad, K. Kvale (2018), "Customer journeys: a systematic literature review", Journal of Service Theory and Practice, Vol. 28, Issue 2, pp.196227, doi: doi.org/10.1108/JSTP-11-2014-0261.

[33] J. Wolny, N. Charoensuksai (2014), "Mapping customer journeys in multichannel decision-making", Journal of Direct, Data and Digital Marketing Practice, Vol. 15, No. 4, pp. 317-326, doi: 10.1057/ dddmp.2014.24.

[34] G.W. Head (1960), "What does automation mean to the Marketing man?", European Journal of Marketing, 24(4), pp. 35-37.

[35] J.C. Gonzálvez, F. Mochón (2016), "Operating an Advertising Programmatic Buying Platform: A Case Study", International Journal of Interactive Multimedia and Artificial Intelligence, Vol. 3, No. 6, pp. 6-15, doi: 10.9781 ijimai.2016.361

[36] A. Klahold (2009), "Empfehlungssysteme: Recommender- Systems Grundlagen, Konzepte und Lösungen”, Wiesbaden, SpringerVieweg.

[37] M. Bala, D. Verma (2018), "A Critical Review of Digital Marketing", International Journal of Management, IT \& Engineering, Vol. 8 Issue 10, October 2018, pp. 321-339.

[38] H. Chen, R.H.L.Chiang, and J.M.R. Storey (2012), "Business intelligence and analytics: from big data to big impact", Mis Quarterly, Vol. 36 No. 4, December 2012, pp. 1165-1188.

[39] K. Krombholz, H. Hobel, M. Huber, and E. Weippl (2014), "Advanced Social Engineering Attack", Journal of Information Security and Applications, 22, pp. 113-122, doi: 10.1016/j.jisa.2014.09.005.

[40] A.-M. Kennedy (2012), "Macro-social marketing and social engineering: a systems approach", Journal of social marketing, Vol. 2, Issue 1, pp.3751, doi: doi.org/10.1108/20426761211203247

[41] J. van Dijck, T. Poell (2013), "Understanding Social Media Logic", Media and Communication, Volume 1, Issue 1, pp. 2-14, doi: 10.12924/ mac2013.01010002.

[42] S. Edosomwan, S. Prakasan, D. Kouame, J. Watson, and T. Seymour (2011), "The history of social media and its impact on business", Journal of Applied Management and Entrepreneurship, No. 16.3 (2011), pp. 7991.

[43] T.L. Tuten, M.R. Salomon (2017), "Social Media Marketing”, London, Sage.

[44] J. Berger, K.I. Milkman (2011), "What Makes online Content Viral?", Journal of Marketing Research, pp. 1-14, doi: 10.1509/jmr.10.0353.

[45] M. Kilgour, S. Sasser, and R. Larke (2015), "The social media transformation process: curating content into strategy", Corporate Communications An International Journal, 20(3), pp. 326-343, doi: 10.1108/CCIJ-07-2014-0046.

[46] G. Mangold, D.J. Faulds (2009), "Social media: The new hybrid element of the promotion mix", Business Horizons, Volume 52, Issue 4, July-August 2009, pp. 357-365, doi: https://doi.org/10.1016/j.bushor.2009.03.002.

[47] A. Kumar, R. Bezawada, R. Rishika, R. Janakiraman, and P.K. Kannan (2016), "From Social to Sale: The Effects of Firm-Generated Content in Social Media on Customer Behavior", Journal of Marketing, Vol. 80 (January 2016), pp. 7-25, doi: dx.doi.org/10.1509/jm.14.0249.

[48] A. Opreana, S. Vinerean (2015), "A New Development in Online Marketing: Introducing Digital Inbound Marketing", Expert Journal of Marketing, Volume 3, Issue 1, pp. 29-34.

[49] E.-E. Sunny, O.J. Anael (2016), "Mobile Marketing in a Digital Age: Application, Challenges \& Opportunities", British Journal of Economics, Management \& Trade, 11(1), pp. 1-13, doi: 10.9734/BJEMT/2016/19925

[50] Á. Nagy, A. Kölcsey (2017), "Generation Alpha: Marketing or Science?", Acta Technologica Dubnicae, volume 7, 2017, issue 1, pp. 107-115, doi: 10.1515/atd-2017-0007.

[51] F. v. Lewinski, (2016), "Lasst die Daten frei - neue Spielräume für Kreativität und Effizienz", w\&w special, Marketing convention 2016, Accessed: Feb. 15, 2019. [Online]. Available: www.wuv.de/specials/w_v_ Marketing_convention_2016/1.

[52] I. Fillis, R. Rentschler (2006), "Creative Marketing: An Extended Metaphor for Marketing in a New Age”, New York, Palgrave Macmillan.

[53] R.L. Flores, S. Negny, J.P. Belaud, and J.-M. Le Lann (2015), "Collective intelligence to solve creative problems in conceptual design phase", World
Conference: TRIZ FUTURE, TF 2011-2014, Procedia Engineering, 131 (2015), pp. 850-860.

[54] K.N. Lemon, P.C. Verhoef (2016), "Understanding Customer Experience Throughout the Customer Journey", Journal of Marketing, AMA/ MSI Special Issue, Vol. 80 (November 2016), pp. 69-96, doi: 10.1509/ jm.15.0420.

[55] C.S. Fleisher (2008), "Using open source data in developing competitive and Marketing Intelligence", European Journal of Marketing, Vol. 42 Issue: 7/8, pp. 852-866, doi: doi.org/10.1108/03090560810877196.

[56] K.J. Trainor, M.T. Krush, R. Agnihotri (2013), "Effects of relational proclivity and Marketing Intelligence on new product development", Marketing Intelligence \& Planning, Vol. 31, Issue 7, pp.788-806, doi: doi. org/10.1108/MIP-02-2013-0028.

[57] J. Wolny, N. Charoensuksai (2014), "Mapping customer journeys in multichannel decision-making", Journal of Direct, Data and Digital Marketing Practice, Vol. 15, No. 4, pp. 317-326, doi: 10.1057/ dddmp.2014.24.

[58] S. Tuzovic, S. Paluch (2018), "Conversational Commerce - A new area for Service Business Development," in: M. Bruhn, K. Hadwich (eds.): Service Business Development: Strategien - Innovationen - Geschäftsmodelle; Forum Dienstleistungsmanagement, Band 1, Wiesbaden, SpringerGabler, pp. 81-100.

[59] C. Messina (2015), "Conversational commerce", Medium, 16. Januar 2015, Accessed: Feb. 15, 2019. [Online]. Available: https://medium.com/ chris-messina/conversational-commerce-92e $0 \mathrm{bccfc} 3 \mathrm{ff}$.

[60] C. Messina, C. (2016), "20016 will be the year of conversational commerce", Medium, 19. Januar 2016, Accessed: Feb. 15, 2019. [Online]. Available: https://medium.com/chris-messina/2016-will-be-the-year-ofconversational-commerce-1586e85e3991.

[61] H. Holland (2014) (ed.), "Digitales Dialogmarketing: Grundlagen, Strategien, Instrumente”, Wiesbaden, SpringerGabler.

[62] M. Anshari, M. N. Almunawar, S. A. Lim, and A. Al-Mudimigh (2018): "Customer relationship management and big data enabled: Personalization \& customization of services", Applied Computing and Informatics, doi: doi.org/10.1016/j.aci.2018.05.004.

[63] F. Lasogga (2014), "Grundlagen und Handlungsfelder für exzellentes Customer Relationship Management", in: Kliewe, T./ Kesting, T. (eds.): Moderne Konzepte des organisationalen Marketing, Wiesbaden, SpringerGabler, pp. 239-254.

[64] T.Y. Chan, C. Wu, Y. Xie (2011), "Measuring the Lifetime Value of Customers Acquired from Google Search Advertising", Marketing Science, Vol. 30, No. 5, September-October 2011, pp. 837-850.

[65] D.M. Hanssens, K.H. Pauwels (2016), "Demonstrating the value of Marketing, Journal of Marketing", Vol 80(6), pp. 173-190, doi: doi. org/10.1509/jm.15.0417.

[66] D. O'Sullivan, A.V. Abela (2007), "Marketing Performance Measurement Ability and Firm Performance", Journal of Marketing, Vol. 71 (April 2007), pp. 79-93, doi: 10.1509/jmkg.71.2.79.

[67] J. Järvinen (2016), "The Use of Digital Analytics for Measuring and Optimizing Digital Marketing Performance”, Jyväskylä University School of Business and Economics, University Library of Jyväskylä. Accessed: Feb. 15, 2019. [Online]. Available: https://jyx.jyu.fi/bitstream/ handle/123456789/51512/978-951-39-6777-2_vaitos21102016. pdf?sequence $=1$

[68] E. Lammenett, (2015), "Praxiswissen Online-Marketing, Affiliate- und E-Mail-Marketing, SuchmaschinenMarketing, OnlineWerbung, Social Media, Online-PR", Wiesbaden, SpringerGabler.

[69] P. Kotler, H. Kartajaya, and I. Setiawan (2017), "Marketing 4.0: Moving from Traditional to Digital", Hoboken, Wiley.

[70] F.T. Lorne, S. Daram, R. Frantz, N. Kumar, A. Mohammed, and A. Muley (2018), "Blockchain Economics and Marketing", Journal of Computer and Communications, 2018, 6, pp. 107-117.

[71] E. Constantinides (2006), "The Marketing Mix Revisited: Towards the 21st Century Marketing", Journal of Marketing Management, 2006, 22, pp. 407-438.

[72] E. Schwedler (2000), "Kompaktwissen Marketing: Grundlagen für Studium und Praxis", Wiesbaden, SpringerGabler.

[73] C.L. Goi (2009), "A Review of Marketing Mix: 4Ps or More?", International Journal of Marketing Studies, Vol. 1, No, pp. 2-15, doi: DOI:10.5539/ijms.v1n1p2. 
[74] S.D. Hunt D. (1976): The Nature and Scope of Marketing, Journal of Marketing, Vol. 40, No. 3 (July, 1976), pp. 17-28.

[75] P. Kotler, S. Levy (1969), "Broadening the Concept of Marketing", Journal of Marketing, Vol. 38, pp. 10-15.

[76] S. Okazaki, B. Mueller, and C.R. Taylor (2010), "Measuring Soft-Sell Versus Hard-Sell Advertising Appeals", Journal of Advertising, vol. 39, no. 2, summer 2010, pp. 5-20, DOI 10.2753/JOA0091-3367390201.

[77] J. Lies (2019), "Marketing 4.0 als "Old School" des PR-Managements", in: M. Stumpf (ed.), Digitalisierung und Kommunikation Konsequenzen der digitalen Transformation für die Wirtschaftskommunikation, Europäische Kulturen in der Wirtschaftskommunikation, Band 31, Wiesbaden, SpringerVS, pp. 231-254.

[78] In further development by A. Opreana, S. Vinerean (2015), “A New Development in Online Marketing: Introducing Digital Inbound Marketing", Expert Journal of Marketing, Volume 3, Issue 1, pp. 29-34.

[79] E. Maltz, A.K. Kohli (1996), "Market Intelligence Dissemination across Functional Boundaries", Journal of Marketing Research, Vol. 33, No. 1, February 1996, pp. 47-61.

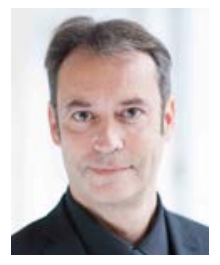

Prof. Dr. habil. Jan Lies

Prof. Dr. Jan Lies has a doctorate and postdoctoral habilitation in economics. Since 2013 he is professor for business administrations, especially corporate communications and marketing at FOM university of applied science in Dortmund, Germany. His research involves evolutionary and behavioral economics as well as digital marketing, pr-management and change communications. Digital marketing is one of his research areas which demonstrates the heavy impact of evolutionary processes on corporate success. 